\title{
A Quantitative Study of Cell Populations in the Circulating Blood of Young Adult Albino Rats*
}

\author{
By
}

\author{
Yoshitoki Monden \\ Department of Anatomy, Yamaguchi Medical School, Ube \\ (Director: Prof. B. Osogoe)
}

In the course of quantitative studies of hematopoietic organs of the rat (Monden, 1955; O sogoe et al., 1957; Osogoe, 1958; O sogoe and Awaya, 1958; and Monden, 1958), it became necessary to make a similar study of the circulating blood of this animal. The present work is an attempt to calculate total cellular numbers of circulating blood in young adult albino rats on the basis of blood cell counts and measurements of circulating blood volume. Normal values for blood counts and circulating blood volume in the rat have been reported by a number of workers, but the published figures show discrepancies.

\section{Material and Methods}

Male albino rats from a subline of the $\mathrm{W}$ is t a $\mathrm{r}$ strain weighing around $200 \mathrm{~g}( \pm 2 \%)$ were chosen as the standard animals to be examined as in the earlier studies (M o n d e n, 1955 and 1958). They were maintained on a standard laboratory diet, which consisted chiefly of unpolisched rice, pressed barley and dried small sardines with a small amount of cod liver oil and minerals, supplemented once a week with cabbage or other vegetables.

Blood examinations were made of flowing blood from the tail vein. For differential cell counts in blood smears, at least 500 cells were observed.

The circulating blood volume was measured by the method of B e r lin et al. (1949) using radioactive phosphorus $\left(\mathrm{P}^{32}\right)$, as described in the preceding paper (Monde $\mathrm{n}, 1955$ ).

\footnotetext{
* Supported in part by a grant to Professor Bunsuke Osogoe from the Ministry of Education (Grant-in-Aid for Fundamental Scientific Research, :Cooperative).
} 


\section{Results and Discussion}

The results of blood cell counts on 50 standard rats are presented in Tables 1 and 2.

As reported previously ( $\mathrm{M}$ o $\mathrm{nde} \mathrm{n}, 1955$ ), the circulating blood volume was estimated to be $11.03 \pm 0.44 \mathrm{ml}^{1}$ from a study of 10 standard rats.

Table 1. Differental counts of nucleated cells in the peripheral blood of the standard rat. Mean of 50 normal male rats with a mean weight of $201 \mathrm{~g}$.

\begin{tabular}{l|c}
\hline Cell Type & $\begin{array}{c}\text { Differential Counts } \\
\text { in Smear }(\%)\end{array}$ \\
\hline Lymphocytes & $70.05 \pm 1.20^{\circ}$ \\
Total Granulocytes & $25.74 \pm 1.33$ \\
Neutrophils & $24.76 \pm 1.14$ \\
Eosinophils & $0.93 \pm 0.17$ \\
Basophils & $0.05 \pm 0.02$ \\
Monocytes & $4.22 \pm 0.25$ \\
\hline
\end{tabular}

* Standard error.

Table 2. The estimated figures* for total numbers of different types of blood cells in the circulating blood of the standard rat (male rat weighing around $200 \mathrm{~g}$ ) and their coefflcients of variation.

\begin{tabular}{l|c|c|c}
\hline \multicolumn{1}{c|}{ Cell Type } & $\begin{array}{c}\text { Average Number } \\
\text { per } \mathrm{mm}^{3} \text { of } \\
\text { Blood }\end{array}$ & $\begin{array}{c}\text { Total Number in } \\
\text { Circulating Blood***} \\
\left(\times 10^{6}\right)\end{array}$ & $\begin{array}{c}\text { Coefficient of } \\
\text { Variation } \\
(\%)\end{array}$ \\
\hline Erythrocytes & $(10.37 \pm 0.45) \times 10^{3}$ & $114,400 \pm 9,380$ & 57.9 \\
Total White Cells & $17,100 \pm 630$ & $189 \pm 14.1$ & 52.5 \\
Lymphocytes & $11,970 \pm 640$ & $132 \pm 12.0^{* * *}$ & 64.3 \\
Total Granulocytes & $4,400 \pm 388$ & $48.5 \pm 6.1$ & 88.8 \\
$\quad$ Neutrophils & $4,234 \pm 350$ & $46.7 \pm 5.6$ & 84.7 \\
Eosinophils & $159 \pm 35$ & $1.75 \pm 0.45$ & 181.0 \\
Monocytes & $722 \pm 71$ & $7.96 \pm 1.06$ & 94.0 \\
\hline
\end{tabular}

* Mean \pm Standard error.

** The mean value for circulating blood volume in standard rat is estimated to be $11.03 \pm 0.44 \mathrm{ml}$.

*** The corresponding value was reported to be $(113 \pm 28) \times 10^{6}$ in the preceeding communications ( $\mathrm{M}$ ond e $\mathrm{n}, 1955$; O s o g o e et al., 1957; and $\mathrm{O}$ s o $\mathrm{g}$ o e, 1958).

1 Standard error. 

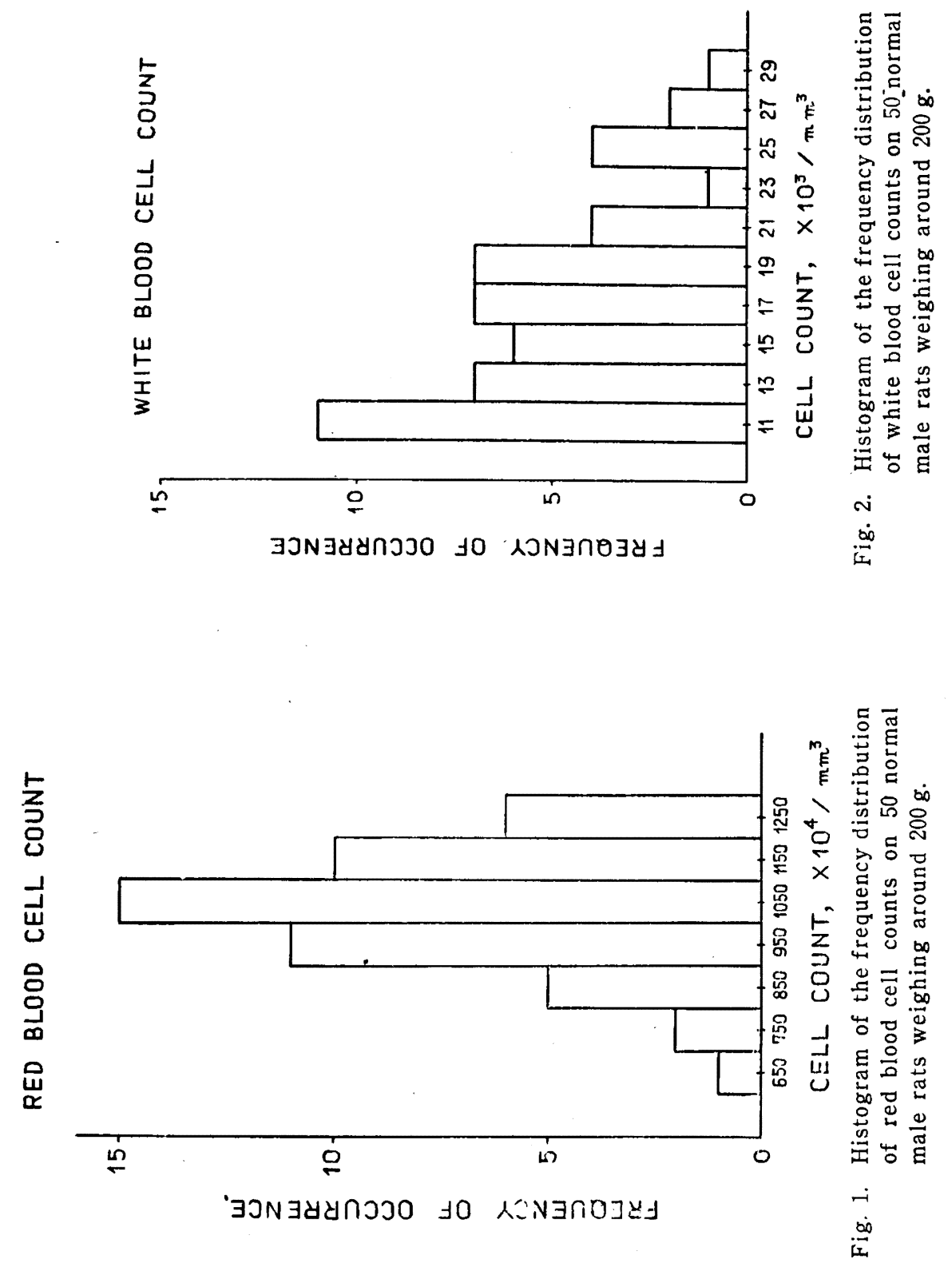


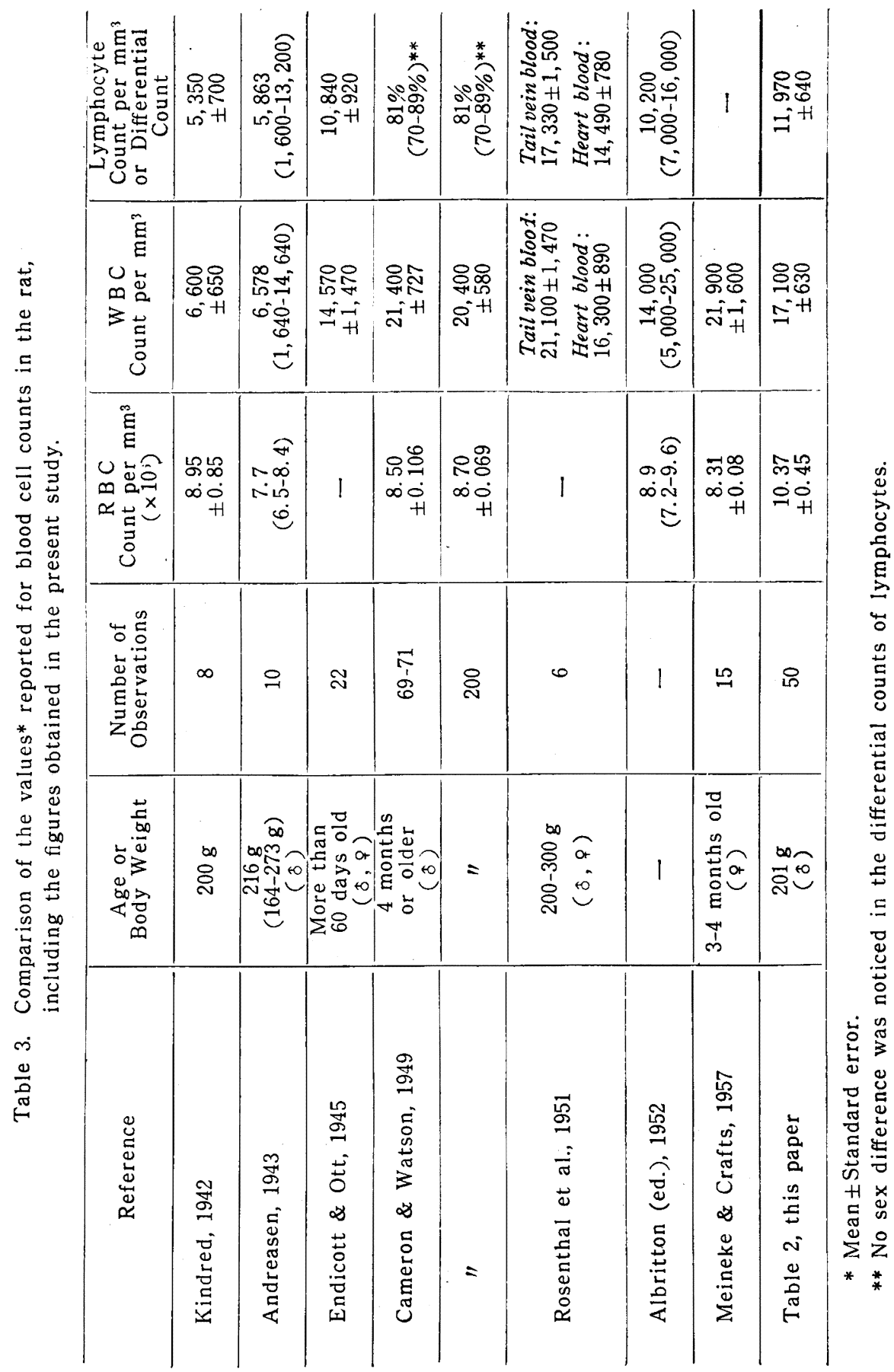


From these data, the total number of each type of blood cells may easily be calculated. The results are given in Table $2,{ }^{2}$ together with variation in the values found for each type of blood cells.

The histograms of the frequency distribution of red cell connts and white cell counts on 50 animals each are show in Figs. 1 and 2. It is of interest to note that the distribution of red cell counts is symmetrical, whereas that of white cell counts asymmeterical and quite irregular.

As shown in Table 3 which survey values for blood cell counts in the rat reported up to the present time, the published figures do not show much variation in the values for red cell counts, which lie between $7.7 \times 10^{6}$ and $8.95 \times 10^{6}$. The mean value from the present observations $\left(10.37 \times 10^{6}\right)$ is greater than the highest values previously reported. In contrast, the reported figures for total white cell (WBC) counts vary from 6,578 to 21,900 per $\mathrm{mm}^{3}$. The mean value $(17,100)$ from the present observations lies between these extremes. The values reported by Kindred (1942) and A ndreasen (1943) for total white cell counts are exceedingly low as compared with the figures of the other workers. Although the reason for this discrepancy is not apparent, it is probable that strain differencies and variations in diet are partly responsible.

As regards the blood cell counts, it is of particular interest that the leukocyte count of heart blood is much lower than that of tail vein blood (cf. Table 3, the figures of $R$ os e $n t h a l$ et al.). Since the present calculations are based solely on the examinations of tail vein blood, the estimated figure for the total number of leukocytes in the circulating blood would probably be in the direction of an overstimate.

The accuracy or reliability of the calculations on the total number of circulating blood cells also depends upon whether the estimated figure for circulating blood volume is quite reasonable or not. Regarding the blond volume in the rat, divergent values are reported in the literature, varying from 4.1 to $10.7 \mathrm{ml}$ per $100 \mathrm{~g}$ of body weight (M o nde n, 1955 and $\mathrm{Be} \mathrm{l} \mathrm{cher} \mathrm{and} \mathrm{Harr}$ is, 1957). However, according to $\mathrm{Belcher}$ and $\mathrm{Harris}$ (1957) who have made an extensive study on young growing rats, the total blood volume per $100 \mathrm{~g}$ of body weight decreases with advancing age, form $7.59 \mathrm{ml}$ in

\footnotetext{
2 The figures are slightly greater than those reported in the preliminary communications (M onde n, 1955; O sogoe et al., 1957; and Osogoe, 1958), $o$ wing to increase in the number of observations.
} 
rats weighing $26-50 \mathrm{~g}$ to $5.10 \mathrm{ml}$ in rats weighing $226-250 \mathrm{~g}$. In the rats weighing around $200 \mathrm{~g}$, the total blood volume is estimated to be either 10.54 or $11.36 \mathrm{ml}$ according to these scholars. Either figure is in good agreement with the figure used in the present study $(11.03 \pm 0.44 \mathrm{ml})$. It can be stated therefore that our figure is quite reasonable.

Finally, the auther wishes to compare the figures obtained in the present study for total cellular numbers of circulating blood with the corresponding values reported by $\mathrm{K}$ i n d $\mathrm{r}$ e d (1942), who made a quite similar calculation based on a study of 8 albino rats weighing approximately $200 \mathrm{~g}$ each. The value used by $\mathrm{K}$ in $\mathrm{dr}$ ed for circulating blood volume was $14.76 \pm 0.27 \mathrm{ml}$ per $200 \mathrm{~g}$ of body weight, and the following figures were obtained : $(136,000 \pm 3,800) \times 10^{5}$ for red cells ; $(104 \pm 2.9) \times 10^{6}$ for total white cells; $(86.6 \pm 5.2) \times 10^{6}$ for lymphocytes ; and $(17.4 \pm 1.9) \times 10^{6}$ for total granulocytes in the circulating blood. From a comparison of these figures with the values given in Table 2 , it is seen that the figures of $\mathrm{Kindred}$ for leuokytes (lymphoctes and granulocytes) are much smaller than the correponding values obtained in the present study. This is attributable to a large extent to the fact that the total white cell count was exceedingly low in the animals used by $\mathrm{K}$ i n d red as compared with that in our material (cf. Table 3).

\section{Summay}

On the basis of the cell counts of tail vein blood from a total of 50 standard rats (male rats weighing around $200 \mathrm{~g}$ from a subline of the $\mathrm{W}$ is ta $\mathrm{r}$ strain) and the measurements of total circulating blood volume on 10 standard rats using radioactive phosphorus, an attempt has been made to calculate total cellular numbers of circulating blood and to present the result.

\section{Refereces}

Albritton, E. C. (ed.) 1952 Standard Values in Blood. W. B. Saunders Comp., Philadelphia and London.

A $n \mathrm{~d} r$ e a se n, E. 1943 Studies on the thymolymphatic system. Acta path. et microbiol. Scandinav., Suppl. XLIX. Ejar Munksgaard, Copenhagen.

Belcher, E. H. and Harris 1957 Studies of plasma volume, red cell volume and total blood volum in young growing rats. J. Physiol., 139:64-78.

Ber 1 in, N. T., R. L. Huff, D. C. Van Dyke and R.F. Hennessy 1949 The blood volume of the adult rat, as determined be $\mathrm{Fe}^{59}$ and $\mathrm{P}^{32}$ labelled red cell. Proc. Soc. Exp. Biol. \& Med., $71:$ 175-178. 
C a m e ron, D. C. and G. H. W a t s o n 1949 The blood counts of the adult albino rat. Blood, $6: 816-818$.

Endicott, K. and M. Ot t 1945 The normal myelogram in albino rats. Anat. Rec., $92: 61-69$.

Kindred, J.E. 1942 A quantitative study of the hematopoietic organs of young adult albino rats. Am. J. Anat., 71:207-243.

Meine ke, H.A. and R. C. C rafts 1957 Further observations on the effect of cortisone and thyroxin on the blood picture of hypophysectomized rats. Blood, 12:11-23

Monden, Y. 1955 Total number of lymphocytes contained in the thymo-lymphatic system of rats as estimated by means of DNA determination. Acta haemat. Jap., 18:617-624. (In Japanese with English summary.)

Monde n, Y. 1958 Quantitative evaluation of total cellular number and cellular density in the thymo-lymphatic organs of young adult albino rats by means of DNA determination. Okajima's Folia anat. Jap., 32 (in press).

Osogoe, B. 1958 A quantiative study of lymphocyte production, with special reference to its relation to myelopoiesis. Saishin-Igaku, 13:1028-1041. (In Japanese.)

O sogoe, B. and K. A w a a 1958 Turnover of cell populations in blood and blood-forming tissue. Acta heamat. Jap., 21 (Suppl.): 408-418.

Osogoe, B., Y. Monde n et H. I to 1957 j tude quantitative de la production cellulaire par le système thymo-lymphatique du rat. Sang., $28: 729-737$.

Rosenthal, R. L., Goldschmidt, and B. J. Pickering 1951 Hematologic changes in rats protected by cystein against total body X-irradiation. Am. J. Physiol., $166: 15-19$. 